\title{
First autochthonous case of canine visceral leishmaniasis in Volta Redonda, Rio de Janeiro, Brazil
}

\author{
Primeiro caso autóctone de leishmaniose visceral canina em Volta Redonda, Rio de Janeiro, Brasil \\ Monique Paiva de Campos ${ }^{1 *}$; Denise Amaro da Silva ${ }^{1}$; Maria de Fátima Madeira²; \\ Artur Augusto Mendes Velho Júnior ${ }^{1}$; Fabiano Borges Figueiredo ${ }^{1}$
}

\begin{abstract}
${ }^{1}$ Laboratório de Pesquisa Clínica em Dermatozoonoses em Animais Domésticos - LAPCLIN-DERMZOO, Instituto de Pesquisa Clínica Evandro Chagas - IPEC, Fundação Oswaldo Cruz - Fiocruz, Rio de Janeiro, RJ, Brasil

${ }^{2}$ Laboratório de Vigilância em Leishmanioses, Instituto de Pesquisa Clínica Evandro Chagas - IPEC, Fundação Oswaldo Cruz Fiocruz, Rio de Janeiro, RJ, Brasil
\end{abstract}

Received February 18, 2013

Accepted March 27, 2013

\begin{abstract}
In Brazil, American visceral leishmaniasis (AVL) is caused by Leishmania (Leishmania) chagasi and its main vector is Lutzomyia longipalpis. Cases of canine visceral leishmaniasis (CVL) in non-endemic areas have been reported over the last few years throughout the country. The objective of this research note is to describe an autochthonous case of CVL that occurred in the municipality of Volta Redonda, state of Rio de Janeiro, an area where the disease is not endemic, alerting veterinarians and the scientific community to the expansion of this important zoonosis and advising veterinary practitioners on how to deal with a suspicion of CVL. Canine visceral leishmaniasis can be misdiagnosed within a broad spectrum of canine diseases based on clinical and laboratory findings. Therefore, knowledge of its clinical manifestations, specific and sensitive laboratory diagnostic tests and parasitological procedures are of the utmost importance for rapid confirmation and notification of a case, thus contributing directly to the control of a focus.
\end{abstract}

Keywords: Canine visceral leishmaniasis, dogs, autochthonous.

\section{Resumo}

No Brasil a leishmaniose visceral americana (LVA) é causada por Leishmania (Leishmania) chagasi e tem como seu principal vetor Lutzomyia longipalpis. Nos últimos anos vêm sendo relatados casos de leishmaniose visceral canina (LVC) em áreas não endêmicas em todo país. O objetivo desta nota é descrever um caso autóctone de LVC no município de Volta Redonda, Estado do Rio de Janeiro, área não endêmica para essa doença e assim, chamar a atenção dos clínicos veterinários e da comunidade científica para a expansão dessa importante zoonose, além de orientar os médicos veterinários, como proceder frente a um caso suspeito de LVC. A LVC pode ser clínica e laboratorialmente confundida com uma ampla gama de patologias caninas e o conhecimento de suas manifestaçóes clínicas e de procedimentos laboratoriais específicos e sensíveis para esse diagnóstico, são de grande importância para uma rápida confirmação e notificação do caso, contribuindo assim diretamente para o controle do foco.

Palavras-chave: Leishmaniose visceral canina, cão, autóctone.

Leishmaniases are zoonotic diseases of public health importance in the world (GRIMALDI; TESH, 1993). The disease is caused by protozoa of the genus Leishmania and is transmitted by the bite of insect vectors of the subfamily Phlebotominae (DEANE; DEANE, 1962; MARZOCHI; MARZOCHI, 1994).

In Brazil, American visceral leishmaniasis (AVL) is caused by Leishmania (Leishmania) chagasi, currently called Leishmania infantum (KUHLS et al., 2011), and its main vector is Lutzomyia

\footnotetext{
${ }^{*}$ Corresponding author: Monique Paiva de Campos

Laboratório de Pesquisa Clínica em Dermatozoonoses em Animais Domésticos

- LAPCLIN-DERMZOO, Instituto de Pesquisa Clínica Evandro Chagas -

IPEC, Fundação Oswaldo Cruz - Fiocruz, Av. Brasil, 4365, Manguinhos,

Rio de Janeiro, RJ, Brasil

e-mail: m.pcampos@yahoo.com.br
}

longipalpis (FRANÇA-SILVA et al., 2005). Since 1980, cases of AVL have been reported in the northeast, north, center-west and southeast of the country. The disease, which was previously restricted to rural areas, is spreading to urban areas (MARZOCHI; MARZOCHI, 1994; BRASIL, 2006; HARHAY et al., 2011).

In view of the broad spectrum of clinical manifestations (MARZOCHI et al., 1985), canine visceral leishmaniasis (CVL) should be diagnosed based on a combination of clinical, laboratory and epidemiological data (GONTIJO; MELO, 2004).

This research note describes the first autochthonous case of CVL recorded in the municipality of Volta Redonda, state of Rio de Janeiro (RJ). In August 2011, a female pit bull, older than 7 years, living in the neighborhood of Minerlândia, Volta Redonda, RJ, without a history of travel, was referred to the Evandro Chagas 
Clinical Research Institute (IPEC), Oswaldo Cruz Foundation, Rio de Janeiro, with an enzyme-linked immunosorbent assay (ELISA) positive for Leishmania and an indeterminate result from the indirect immunofluorescence test (IIF) performed in a private laboratory. Over a period of 6 months, the overall health condition of the dogs appeared normal although it was thin and normothermic; the mucosa had normal color with alopecia, diffuse furfuraceous desquamation, opaque skin, ulcers covered with scabs and mucopurulent conjunctival discharge.

The animal was sedated with an intramuscular injection of ketamine hydrochloride $(10 \mathrm{mg} / \mathrm{kg})$ and acepromazine $(0.2 \mathrm{mg} / \mathrm{kg})$. Blood (approximately $5 \mu \mathrm{L}$ ) was collected from the earlobe for the rapid Dual Path Platform ${ }^{\mathrm{TM}}$ (DPP) CVL immunochromatographic test. For IIF and ELISA, about $5 \mathrm{~mL}$ of blood without anticoagulant was collected by cephalic venipuncture.

After shaving, washing with soap and water, antisepsis with $70 \%$ alcohol and local anesthesia with 2\% lidocaine hydrochloride without a vasoconstrictor, intact skin biopsies were obtained from three sites in the scapular region, using a 3-mm punch. The fragments were stored in $10 \%$ buffered formaldehyde and processed for hematoxylin-eosin staining and immunohistochemistry. In addition, a bone marrow aspirate was obtained from the sternum (manubrium). One of the intact skin fragments was stored in sterile saline containing $100 \mu \mathrm{g} / \mathrm{mL}$ 5-fluorocytosine, 1,000 IU/ $\mathrm{mL}$ penicillin $\mathrm{G}$ potassium and $200 \mu \mathrm{g} / \mathrm{mL}$ streptomycin, and subsequently seeded in biphasic Novy-MacNeal-Nicolle (NNN) culture medium containing Schneider's medium supplemented with $10 \%$ fetal bovine serum as liquid phase. The bone marrow aspirate was directly seeded in NNN medium. Multilocus enzyme electrophoresis was used to characterize the Leishmania isolate (CUPOLILLO et al., 1994).

Anti-Leishmania specific antibodies were detected by IFF, ELISA and DPP at a reference center. A histopathological analysis of the intact skin fragment showed chronic nodular granulomatous dermatitis accompanied by interstitial and periadnexal mononuclear inflammatory infiltrate. The infiltrate consisted mainly of plasma cells and macrophages whose cytoplasm contained vacuoles with variable numbers of amastigote forms. Immunohistochemistry revealed the presence of numerous amastigotes compatible with Leishmania sp. promastigote forms isolated from the intact skin culture and bone marrow samples were identified as L. (Leishmania) chagasi by isoenzyme analysis. The animal died one week after examination.

We describe the first autochthonous case of CVL in Volta Redonda, RJ, Brazil. This case report, like previous ones, contributes to warn about the dissemination of CVL to previously nonendemic areas. For example, an earlier CVL case was reported in Jaboticabal, São Paulo (SAKAMOTO et al., 2007), and in Marica, Rio de Janeiro (PAULA et al., 2009); the first cases described in those municipalities. In 2011, another CVL case was described in Cachoeiras de Macacu, Rio de Janeiro (SILVA et al., 2011). Although the case was not autochthonous, it may have contributed to maintain the cycle in the region, since the presence of susceptible sand flies associated with human and canine migration, disorganized land occupation leading to the environmental degradation of protected areas, and low socioeconomic conditions may cause an epidemic (MARZOCHI et al., 2009).
The animals included in the above cited studies showed clinical signs similar to those presented by the dog described here. This dog and other cases were also diagnosed based on signs and symptoms (clinical examination). Knowledge of the disease and its clinical manifestations is of the utmost importance when there is a suspicion of CVL and in order to implement further measures such as the application of serological and histochemical techniques, biochemical studies, etiologic confirmation by means of golden-standard parasitological techniques, and lastly, notification of the case.

A suspected case of visceral leishmaniasis in a child from Volta Redonda (RIO DE JANEIRO, 2012) was notified during the study period described here. Canine cases generally precede human cases. In Minas Gerais, Silva et al. (2001) reported an increase in the notification of CVL cases followed by human cases in the metropolitan region of Belo Horizonte.

Some measures can be adopted to prevent this type of dissemination, such as a better control of travel conditions of dogs from endemic areas, implementation of obligatory serological screening of travelling dogs, compulsory notification of positive canine cases, and educational measures designed to raise the awareness of dog owners, veterinary practitioners and civil society (FIGUEIREDO et al., 2012). According to Thomaz-Soccol et al. (2009), the migration of such animals can disseminate the parasite to other regions, provided the agent finds an adequate ecotope and a specific vector (Lutzomyia longipalpis). In addition, the appropriate government agencies should intensify control measures in "silent" municipalities where no cases of CVL have yet been notified despite the vector's presence, to enable the implementation of disease control strategies.

\section{Acknowledgements}

This study was supported by Fundação de Amparo à Pesquisa do Estado do Rio de Janeiro (FAPERJ)-Estudo de doenças negligenciadas e reemergentes and Conselho Nacional de Pesquisa e Desenvolvimento (CNPq). FBF holds a grant from $\mathrm{CNPq}$ for productivity in research.

\section{References}

Brasil. Ministério da Saúde. Manual de Vigilancia e Controle da Leishmaniose Visceral. Brasília: Ministério da Saúde; 2006. p. 122. Available from: http://portal.saude.gov.br/portal/arquivos/pdf/manual_ leish_visceral2006.pdf.

Cupolillo E, Grimaldi G Jr, Momen H. A general classification of new world Leishmania using numerical zymotaxonomy. Am J Trop Med Hyg 1994; 50(3): 296-311. PMid:8147488.

Deane LM, Deane MP. Visceral Leishmaniasis in Brazil: Geographical Distribution and Transmission. Rev Inst Med Trop São Paulo 1962; 4(1): 198-212. PMid:13884626.

Figueiredo FB, Lima FEF Jr, Tomio JE, Indá FMC, Corrêa GLB, Madeira MF. Leishmaniose Visceral Canina: Dois casos autóctones no município de Florianópolis, estado de Santa Catarina. Acta Sci Vet 2012; 40(1): 1026. 
França-Silva JC, Barata RA, Costa RT, Monteiro EM, MachadoCoelho GL, Vieira EP, et al. Importance of Lutzomyia longipalpis in the dynamics of transmission of canine visceral leishmaniasis in the endemic area of Porteirinha municipality, Minas Gerais, Brazil. Vet Parasitol 2005; 131(3-4): 213-220. PMid:15975718. http://dx.doi. org/10.1016/j.vetpar.2005.05.006

Gontijo CMF, Melo MN. Leishmaniose visceral no Brasil: quadro atual, desafios e perspectivas. Rev Bras Epidemiol 2004; 7(3): 338-349. http:// dx.doi.org/10.1590/S1415-790X2004000300011

Grimaldi GJ, Tesh RB. Leishmaniases of the New World: current concepts and implications for future research. Clin Microbiol Rev 1993; 6(3): 230250. PMid:8358705 PMCid:358284.

Harhay MO, Olliaro PL, Costa DL, Costa CH. Urban parasitology: visceral leishmaniasis in Brazil. Trends Parasitol 2011; 27(9): 403-409. PMid:21596622. http://dx.doi.org/10.1016/j.pt.2011.04.001

Kuhls K, Alam MZ, Cupolillo E, Ferreira GEM, Mauricio IL, Oddone $\mathrm{R}$, et al. Comparative microsatellite typing of New World Leishmania infantum reveals low heterogeneity among populations and its recent old world origin. PLoS Negl Trop Dis 2011; 5(6): e1155. http://dx.doi. org/10.1371/journal.pntd.0001155

Marzochi MCA, Coutinho SG, De Souza WJS, De Toledo LM, Grimaldi G Jr, Momen H, et al. Canine visceral leishmaniasis in Rio de Janeiro, Brazil. Clinical, parasitological, therapeutical and epidemiological findings (1977-1983). Mem Inst Oswaldo Cruz 1985; 80(3): 349-357. PMid:3837171. http://dx.doi.org/10.1590/S0074-02761985000300012

Marzochi MCA, Fagundes A, Andrade MV, Souza MB, Madeira MF, Mouta-Confort E, et al. Visceral leishmaniasis in Rio de Janeiro, Brazil: eco-epidemiological aspects and control. Rev Soc Bras Med Trop 2009; 42(5): 570-580. PMid:19967242. http://dx.doi.org/10.1590/ S0037-86822009000500017
Marzochi MCA, Marzochi KBF. Tegumentary and visceral leishmaniases in Brazil - Emerging anthropozoonosis and possibilities for their control. Cad Saúde Públ 1994; 10(S2): 359-375. PMid:15042226. http://dx.doi. org/10.1590/S0102-311X1994000800014

Paula CC, Figueiredo FB, Menezes RC, Mouta-Confort E, Bogio A, Madeira MF. Leishmaniose visceral canina em Maricá, Estado do Rio de Janeiro: relato do primeiro caso autóctone. Rev Soc Bras Med Trop 2009; 42(1): 77-78. PMid:19287941. http://dx.doi.org/10.1590/ S0037-86822009000100016

Rio de Janeiro. Coordenação de Vigilância Epidemiológica. Divisão de Transmissíveis e Imunopreviníveis. Gerência de Doenças Transmitidas por Vetores e Zoonoses. Nota técnica no 5/2012. Rio de Janeiro: DGS; 2012. Available from: http://www.dgs.cbmerj.rj.gov.br/modules.php?name=N ews\&file $=$ article $\&$ sid $=538$.

Sakamoto CAM, Bresciani KDS, Serrano ACM, Lima VMF, Machado GF, Kanamura CT, et al. Leishmaniose visceral canina em Jaboticabal - SP - primeiro caso. Ars Vet 2007; 23(3): 125-128.

Silva DA, Perié CSFS, Mundes Júnior AAV, Madeira MF, Figueiredo FB. Leishmaniose Visceral Canina em Cachoeiras de Macacu, RJ - Relato de Caso. Clin Vet 2011; 95: 64-68.

Silva ES, Gontijo CMF, Pacheco RS, Fiuza VOP, Brazil RP. Visceral Leishmaniasis in the Metropolitan Region of Belo Horizonte, State of Minas Gerais, Brazil. Mem Inst Oswaldo Cruz 2001; 96(3): 285 291. PMid:11313633. http://dx.doi.org/10.1590/S007402762001000300002

Thomaz-Soccol V, Castro EA, Navarro IT, Farias MR, Souza LM, Carvalho Y, et al. Casos alóctones de Leishmaniose visceral canina no Paraná, Brasil: implicações epidemiológicas. Rev Bras Parasitol Vet 2009; 18(3): 46-51. http://dx.doi.org/10.4322/rbpv.01803008 